\title{
Bone changes in congenital cyanotic heart disease
}

\author{
Harbans Singh, A. Parkash, M. Saini, and P. L. Wahi \\ From the Departments of Medicine, Pathology, and Radiology, \\ Postgraduate Institute of Medical Education and Research, Chandigarh, India
}

Twenty-five patients with congenital cyanotic heart disease were studied. Skiagrams of the skull (posteroanterior and lateral views), pelvis and lumbar spine (posteroanterior and lateral views), upper limb (posteroanterior view only), and x-ray of ankle joint including lower ends of tibia and fibula (posteroanterior and lateral views) were taken.

Haemoglobin, packed cell volume, total leucocyte count, differential leucocyte count, and reticulocyte count were done in each case by standard techniques. Bone marrow was examined in 20 cases.

Out of the 25 patients, 4 showed radiological evidence of hypertrophic osteoarthropathy. These patients had a severer degree of polycythaemia as judged by packed cell volume. Age and duration of illness were not important factors.

'Other bone changes' such as widening of diploe, 'hair on end' striations, widening of medullary canals, and coarse trabecular pattern were present in 12 out of the 25 patients (including the 4 patients showing hypertrophic osteoarthropathy). Patients showing 'other bone changes' had severer degree of polycythaemia as judged by packed cell volume and haemoglobin, were older, and had longer duration of illness.

Nine out of I2 patients showing radiological bone changes had hypercellular bone marrow.

Clubbing is a regular and constant feature in cyanotic congenital heart disease, but pulmonary osteoarthropathy is very rare. Some bone changes such as widening of diploe, 'hair on end' striations, widening of medullary canals, coarse trabecular pattern, and mottled areas of sclerosis in the spine and ribs have been described in cyanotic heart disease as isolated case reports or as small series (Ascenzi and Marinozzi, 1958; Mariani and Bosman, 1962; Nice, Daves, and Wood, 1964). However, these authors did not investigate the correlation of these bone changes with the haematological data, in spite of the fact that they used the analogy of bone changes in haemolytic anaemias in explaining these radiological bone changes.

We thought it worth while to investigate this aspect to find out (a) frequency of pulmonary osteoarthropathy in congenital cyanotic heart disease, (b) frequency of other bone changes, and (c) correlation, if any, of osteoarthropathy and other bone changes with age, duration of cyanosis, or haematological findings.

Received 7 June 1971 .

\section{Material and methods}

For this study we took 25 cases of congenital cyanotic heart disease irrespective of their basic lesion. Most of these patients were admitted to Nehru Hospital of Postgraduate Institute of Medical Education and Research, Chandigarh, but some were investigated from the outpatient clinic.

Cardiac diagnosis was based on clinical, radiological, and electrocardiographic data. In suitable cases cardiac catheterization and selective cardioangiography and cardiac surgery confirmed the clinical diagnosis. Skiagrams of the following bones were done in all cases: (i) $x$-ray of skull, posteroanterior and lateral views; (ii) $x$-ray of pelvis and lumbar spine, posteroanterior and lateral views; (iii) $x$-ray of upper limb including wrist and elbow joints, posteroanterior view only; (iv) $x$-ray of ankle joint including lower ends of tibia and fibula, posteroanterior and lateral views.

The following haematological investigations were carried out in every case. (i) Haemoglobin estimation by the oxyhaemoglobin method using Grey-wedge photometer. (ii) Packed cell volume, total leucocyte count, reticulocyte count, and differential leucocyte count were done by usual standard techniques. (iii) Peripheral smear was examined for hypochromia of red cells in all the cases. (iv) Bone marrow examination was 
done in 20 cases. In 12 cases Salah needle was used for the aspiration of bone marrow from the sternum. The smears were stained with Leishman's stain. In 8 patients, in whom a shunt operation was done, a piece of rib was obtained at the time of operation and the decalcified sections were stained with haematoxylin and eosin stain.

\section{- Observations}

Out of 25 patients studied, 20 were male and 5 were female. Their ages ranged from 2 to 24 years (Table I).

Duration of symptoms varied from 2 to $22 \frac{1}{2}$ years. All the patients had limitation of exercise tolerance of grade 2-3 (New York Heart Association) and all had clubbing and cyanosis. Both these findings were arbitrarily graded into mild, moderate, and severe on clinical assessment. The cardiac diagnoses are shown in Table 2.

Three cases had pain, swelling, and increased warmth around the wrist or ankle joints or both. In 2 patients these changes were noticed around the ankle joints only. In I case similar changes were noticed around the ankle joints as well as the wrist joints.

\section{Bone changes in cyanotic heart disease} The bone changes were divided into (i) hypertrophic osteoarthropathy and (ii) 'other bone changes' such as widening of diploe and 'hair on end' striations in the skull, widening of medullary cavity in long bones, and coarse trabeculations in the pelvis and lumbar spine.

Four out of 25 patients showed radiological evidence of osteoarthropathy, i.e. periostitis. In 2 patients periostitis was present in the distal part of the tibia and ulna. In the remaining 2 cases, periostitis was limited to the distal part of the tibia in one and to the ulna in the other (Fig. I).

Twelve out of the 25 patients showed 'other bone changes' to a varying degree, including the 4 cases with osteoarthropathy (Table 3 ). Only I case had classical 'hair on end'

TABLE I Number of cases according to age groups

\begin{tabular}{cc}
\hline Age $(y r)$ & No. of cases \\
\hline I-6 & 9 \\
$7-10$ & 9 \\
11-15 & 1 \\
$16-20$ & 4 \\
$21-25$ & 2 \\
\hline Total & 25 \\
\hline
\end{tabular}
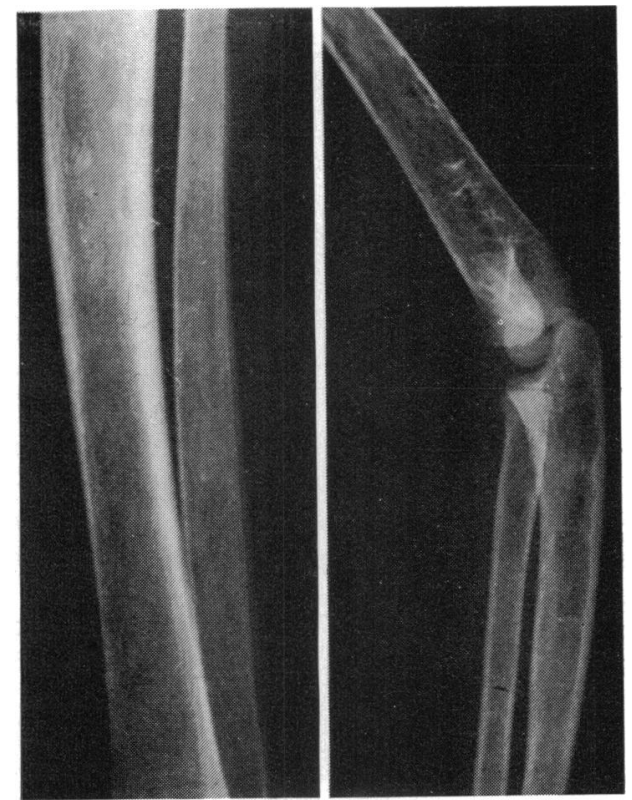

I

3
FIG. I Lateral view of tibia and fibula showing periostitis involving fibula.

FIG. 2 Supine view of pelvis, showing coarsening of trabecular pattern and widening of medullary canal of upper end of femur.

FIG. 3 Conspicuous widening of medullary canal of humerus.

2

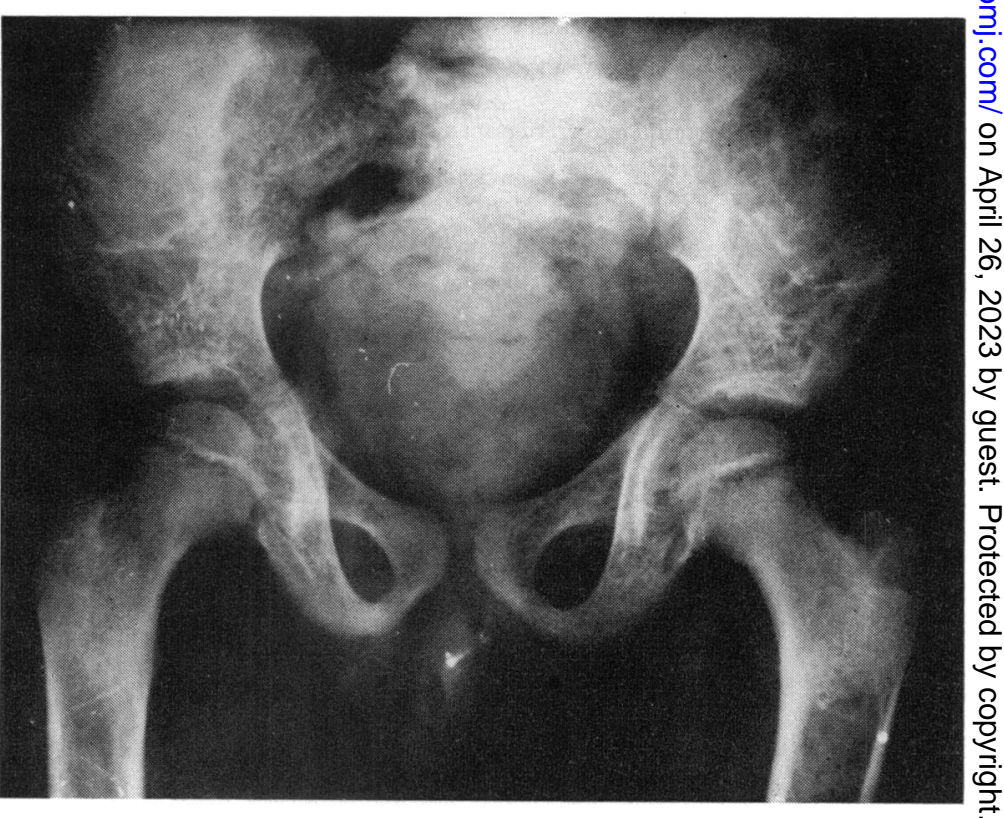


TABLE 2 Diagnoses of various patients

\begin{tabular}{ll}
\hline Diagnosis & $\begin{array}{l}\text { No. of } \\
\text { patients }\end{array}$ \\
\hline Fallot's tetralogy & I5 \\
Tricuspid atresia & 3 \\
Ebstein's anomaly & 2 \\
Isolated laevocardia with pulmonary & I \\
$\quad$ stenosis and complex intracardiac & \\
defects & 4 \\
\hline Unclassified cyanotic heart disease & 25 \\
\hline
\end{tabular}

striations in the $x$-ray of the skull. Five out of the 25 cases showed widening of the diploe in the $x$-ray of the skull. Conspicuous coarsening of the trabecular pattern in the pelvic bones and spine was present in 6 cases (Fig. 2). Eight patients showed widening of the medullary cavity of the long bones (Fig. 3).

Haematological study Haematological study showed a varying degree of polycythaemia in all except 3 cases. The total leucocyte count and differential leucocyte and reticulocyte counts were within normal limits. The peripheral blood smear showed hypochromia in 4 cases.

The bone marrow was examined in 20 cases. Fourteen patients showed hypercellularity of the bone marrow. In 4 patients, it was normocellular. In 2 patients, no comment could be made regarding cellularity because the sample was inadequate. Vascular congestion was found in 2 patients with hypercellular marrow (Fig. 4). One patient with hypercellular marrow showed areas of decreased cellularity and patchy sclerosis.

Correlation of haemoglobin, packed cell volume, age, and duration of cyanosis in patients with and without osteoarthropathy The patients with osteoarthropathy had a severer degree of polycythaemia as judged by the packed cell volume. There was no statistically significant difference between the age and duration of cyanosis in cases with and without osteoarthropathy (Table 4).

A similar correlation with 'other bone changes' is shown in Table 5 .

There is a statistically significant difference between haemoglobin, packed cell volume,

TABLE 3 Age, diagnosis, and bone changes in cyanotic heart disease

\begin{tabular}{|c|c|c|c|c|c|c|}
\hline \multirow{2}{*}{$\begin{array}{l}\text { Case } \\
\text { No. }\end{array}$} & \multirow{2}{*}{$\begin{array}{l}\text { Age } \\
(y r) \\
\text { and } \\
\text { sex }\end{array}$} & \multirow[t]{2}{*}{ Diagnosis } & \multirow{2}{*}{$\begin{array}{l}\text { Osteo- } \\
\text { arthro- } \\
\text { pathy }\end{array}$} & \multicolumn{3}{|l|}{ Other bone changes } \\
\hline & & & & Skull & Long bones & $\begin{array}{l}\text { Pelvis and } \\
\text { lumbar spine }\end{array}$ \\
\hline $\mathbf{I}$ & $3 \frac{1}{2} M$ & Fallot's tetralogy & Present & Nil & $\begin{array}{l}\text { Widening of } \\
\text { medullary cavity }\end{array}$ & $\begin{array}{l}\text { Coarse trabecular } \\
\text { pattern }\end{array}$ \\
\hline 2 & $24 F$ & Fallot's tetralogy & Present & $\begin{array}{l}\text { Widening of } \\
\text { diploe }\end{array}$ & $\begin{array}{l}\text { Widening of } \\
\text { medullary cavity }\end{array}$ & $\mathrm{Nil}$ \\
\hline 3 & $7 \frac{1}{2} M$ & Fallot's tetralogy & Present & $\begin{array}{l}\text { 'Hair on end' } \\
\text { striations, } \\
\text { widening of } \\
\text { diploe }\end{array}$ & Nil & $\begin{array}{l}\text { Coarse trabecular } \\
\text { pattern }\end{array}$ \\
\hline 4 & I6 M & Fallot's tetralogy & Present & Nil & $\begin{array}{l}\text { Widening of } \\
\text { medullary cavity }\end{array}$ & Nil \\
\hline 5 & $6 M$ & Fallot's tetralogy & Nil & Nil & Nil & $\begin{array}{l}\text { Coarse trabecular } \\
\text { pattern }\end{array}$ \\
\hline 6 & $18 \mathrm{M}$ & Fallot's tetralogy & Nil & Nil & $\begin{array}{l}\text { Widening of } \\
\text { medullary cavity }\end{array}$ & Nil \\
\hline 7 & $5 \frac{1}{2} F$ & Fallot's tetralogy & Nil & Nil & Nil & $\begin{array}{l}\text { Coarse trabecular } \\
\text { pattern }\end{array}$ \\
\hline 8 & $8 \mathrm{M}$ & Fallot's tetralogy & Nil & Widening of diploe & Nil & $\mathrm{Nil}$ \\
\hline 9 & 2 I F & Ebstein's anomaly & Nil & $\begin{array}{l}\text { Widening of diploe } \\
\text { and coarse } \\
\text { trabeculations }\end{array}$ & $\begin{array}{l}\text { Widening of } \\
\text { medullary cavity }\end{array}$ & $\begin{array}{l}\text { Coarse trabecular } \\
\text { pattern }\end{array}$ \\
\hline 10 & $12 \mathrm{M}$ & $\begin{array}{l}\text { ?Transposition of } \\
\text { great arteries with } \\
\text { pulmonary stenosi }\end{array}$ & Nil & $\begin{array}{l}\text { Widening of diploe } \\
\text { and coarse } \\
\text { trabeculations }\end{array}$ & $\begin{array}{l}\text { Widening of } \\
\text { medullary cavity }\end{array}$ & $\begin{array}{l}\text { Coarse trabecular } \\
\text { pattern }\end{array}$ \\
\hline I I & I6 M & $\begin{array}{l}\text { ?Transposition of } \\
\text { great arteries }\end{array}$ & Nil & Nil & $\begin{array}{l}\text { Widening of } \\
\text { medullary cavity }\end{array}$ & Nil \\
\hline 12 & I6 M & ?Single ventricle & Nil & Nil & $\begin{array}{l}\text { Widening of } \\
\text { medullary cavity }\end{array}$ & Nil \\
\hline
\end{tabular}


duration of cyanosis, and age in patients with 'other bone changes' as compared with those without bone changes. These patients had a more severe degree of polycythaemia as judged by the haemoglobin and packed cell volume. They were older and had a longer duration of cyanosis.

Altogether I2 patients showed radiological bone changes. Out of these, 9 patients had a

- hypercellular marrow including the 4 with osteoarthropathy. Two patients with a normocellular bone marrow also showed bone changes. Five patients with a hypercellular bone marrow showed no bone changes. The majority of patients with radiological bone changes including osteoarthropathy showed

- a hypercellular bone marrow.

\section{Discussion}

Hypertrophic osteoarthropathy associated with congenital cyanotic heart disease, though well documented, is considered a rare and poorly understood entity. Trever (1958) cited an incidence of $O . I$ per cent in a large series of 3000 cases of cyanotic heart disease. However, he did not define his criteria of pulmonary osteoarthropathy, which we think is an essential prerequisite.

Ginsburg (1963) felt that the diagnostic feature of osteoarthropathy was periostitis which on $x$-ray is seen as a thin irregular radio-opaque line of new bone at the distal end of the diaphyses, separated from the underlying cortex by a narrow radiotranslucent band. In advanced cases periostitis increases and eventually fuses with the cortex of the shaft. According to him, joints are never involved though effusion and pain in joints may occur. The overlying soft tissue neovascularization manifests by warmth, tenderness, and oedema. Our criteria for the diagnosis of hypertrophic osteoarthropathy were similar to those postulated by Ginsburg (1963).

Comparison of our findings with Trever's large series raises many questions. There is an $\checkmark$ enormous difference in the incidence of osteoarthropathy in the two series. As mentioned earlier, Trever had not clearly mentioned his criteria of osteoarthropathy. His study was most probably a retrospective study of case records. Trever's communication also fails to mention whether a skeletal survey was routine or only done in those cases strongly suspected on clinical grounds. It is obvious that such a difference is not likely to be explained by chance or selectivity though some degree of selectivity in our series cannot be excluded. It is very likely that the high

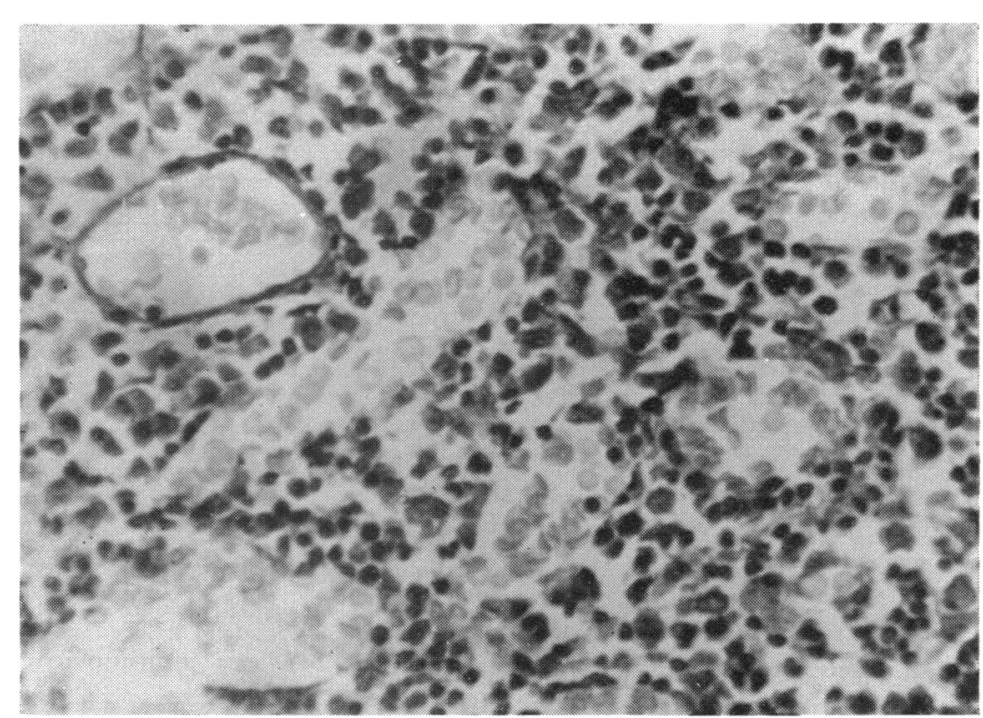

FIG. 4 Photomicrograph showing increased cellularity and vascular congestion of bone marrow. (H. and E. $\times 660$.)

incidence in our series is the product of a number of factors, that is prospective searching, clinical examination, and detailed skeletal survey in every case. Another factor might have been the fact that cases of congenital cyanotic heart disease in this country are not offered surgical treatment routinely and early, and some of them develop osteoarthropathy. However, we failed to find any statistically significant difference between the age and duration of cyanosis in patients with and without osteoarthropathy.

The patients with hypertrophic osteoarthropathy had severer degrees of polycythaemia as judged by packed cell volume and this was statistically significant $(P<0.05)$. The aetiology of hypertrophic osteoarthropathy remains an enigma. No single postulated mechanism accounts for the existence of osteoarthropathy in association with a number of seemingly unrelated conditions. The assumption that osteoarthropathy is merely an advanced stage of clubbing (Mendlowitz and Leslie, 1942) is, therefore, not justified and one may conclude that the onset of periostitis depends on factors different or unrelated to production of finger clubbing (Ginsburg, 1963).

Intrinsic bone changes in cyanotic heart disease Ascenzi and Marinozzi (1958) were apparently the first to describe thickening and bristling of skull bones similar to Cooley's 
anaemia in 2 cases of congenital cyanotic heart disease. Mariani and Bosman (1962) did a skeletal survey in 26 cases of cyanotic heart disease. Their study included skiagrams of the skull in 18, and of the sternum and spine in 25 patients. They found diploic thickening of the skull in 3 cases and slight thinning of the upper and lower margins of vertebral bodies in 6 cases. The sternum was involved in only I case. Microscopical studies showed marrow hyperplasia in all cases which was more pronounced in older patients. Nice et al. (1964) described bone changes similar to those seen in chronic haemolytic anaemias in 6 patients with congenital cyanotic heart disease.

We found changes almost similar to those reported by Nice et al. (1964), such as widening of diploe of skull, 'hair on end' striations, widening of medullary canal of long bones, and coarse trabecular pattern. Twelve out of 25 patients showed this type of bone change to a varying degree. These included the 4 cases with osteoarthropathy. However, we did not find in any of our cases mottled areas of sclerosis in the spine and ribs as described by Nice et al. (1964).

Patients showing these bone changes had a severer degree of polycythaemia as judged by haemoglobin and packed cell volume when compared with those who did not show bone changes, and this was statistically significant $(\mathbf{P}<0.01)$. The patients with these bone changes were older and had longer duration of cyanosis $(P<0.01)$. Nine out of 12 patients showing radiological bone changes including osteoarthropathy had hypercellular bone marrow. One of these patients had areas of decreased cellularity and patchy sclerosis.

The pathogenesis of these bone changes is considered to be a hyperplastic marrow (Nice et al., 1964) which may result from constant stimulation due to hypoxia, causing widening of the medullary canal, widening of diploe, endosteal cortical defects, and coarse trabeculations. The majority of patients showing bone changes had a hypercellular marrow and a more severe degree of polycythaemia, supporting the view that a hyperplastic marrow is responsible for these changes.

The exact mechanism of sclerotic bone changes reported by Nice et al. (1964) is not clear. These changes may be due either to deposition of new bone on existing bone, or to osseous metaplasia in marrow spaces (Nice et al., 1964). The possibility that infarction plays some role in producing sclerotic changes, because bone infarction does produce sclerosis, cannot be ruled out. Infarction is likely to occur in the presence of polycythaemia which
TABLE 4 Statistical significance of haemoglobin, packed cell volume, age, and duration of cyanosis in patients with and without osteoarthropathy

\begin{tabular}{|c|c|c|c|c|c|}
\hline & \multicolumn{2}{|c|}{$\begin{array}{l}\text { Patients with } \\
\text { osteoarthropathy }\end{array}$} & \multicolumn{2}{|c|}{$\begin{array}{l}\text { Patients without } \\
\text { osteoarthropathy }\end{array}$} & \multirow[t]{2}{*}{$\begin{array}{l}\text { Significance } \\
\text { (' } t \text { ' test) }\end{array}$} \\
\hline & Mean & $S D$ & Mean & $S D$ & \\
\hline $\begin{array}{l}\text { Haemoglobin } \\
\qquad(\mathrm{g} / \mathrm{1} \infty 0 \mathrm{ml})\end{array}$ & $21 \cdot 65$ & 0.67 & I $8 \cdot 47$ & $4 \cdot 02$ & $P>0.05$ \\
\hline $\begin{array}{l}\text { Packed cell } \\
\text { volume (\%) }\end{array}$ & $66 \cdot 50$ & $2 \cdot 87$ & $55 \cdot 38$ & $9 \cdot 07$ & $\mathbf{P}<0.05$ \\
\hline $\begin{array}{l}\text { Duration of } \\
\text { cyanosis (yr) }\end{array}$ & $I I \cdot 8 I$ & $8 \cdot 38$ & $8 \cdot 11$ & $3 \cdot 18$ & $P>0.05$ \\
\hline Age (yr) & $12 \cdot 75$ & $3 \cdot 19$ & $8 \cdot 17$ & $5 \cdot 31$ & $\mathbf{P}>0.05$ \\
\hline
\end{tabular}

is very common in congenital cyanotic heart disease.

\section{Conclusions}

I) Hypertrophic osteoarthropathy in association with congenital cyanotic heart disease is not so rare as the published reports suggest (Vogl, Blumenfeld, and Gutner, 1955).

2) 'Other bone changes' are very frequent in congenital cyanotic heart disease. These were noted in 48 per cent of the 25 cases.

3) Patients with hypertrophic osteoarthropathy have severe polycythaemia as judged by packed cell volume. The age and duration of illness are not important factors.

4) Patients showing 'other bone changes' also have a more severe degree of polycythaemia, are older, and have a longer duration of cyanosis as compared to those with no bone changes.

5) The majority of patients showing radiological bone changes have hypercellular bone marrow.

TABLE 5 Statistical significance of haemoglobin, packed cell volume, age, and duration of cyanosis in patients with and without

'other bone changes'

\begin{tabular}{|c|c|c|c|c|c|}
\hline & \multicolumn{2}{|c|}{$\begin{array}{l}\text { Patients with } \\
\text { bone changes }\end{array}$} & \multicolumn{2}{|c|}{$\begin{array}{l}\text { Patients without } \\
\text { bone changes }\end{array}$} & \multirow[t]{2}{*}{$\begin{array}{l}\text { Significance } \\
\text { (' } t \text { ' test })\end{array}$} \\
\hline & Mean & $S D$ & Mean & $S D$ & \\
\hline $\begin{array}{l}\text { Haemoglobin } \\
\quad(\mathrm{g} / \mathrm{roO} \mathrm{ml})\end{array}$ & $21 \cdot 53$ & $I \cdot 02$ & 16.09 & I.94 & $P<0.01$ \\
\hline $\begin{array}{l}\text { Packed cell } \\
\text { volume (\%) }\end{array}$ & $65 \cdot 25$ & $2 \cdot 96$ & $49 \cdot 69$ & $6 \cdot 32$ & $P<0.01$ \\
\hline $\begin{array}{l}\text { Duration of } \\
\text { cyanosis }(\mathrm{yr})\end{array}$ & $11 \cdot 52$ & $6 \cdot 73$ & $4 \cdot 69$ & $2 \cdot 27$ & $\mathbf{P}<0.0 \mathrm{I}$ \\
\hline Age $(y r)$ & $12 \cdot 17$ & $6 \cdot 73$ & $5 \cdot 33$ & $2 \cdot 53$ & $P<0.01$ \\
\hline
\end{tabular}




\section{References}

Ascenzi, A., and Marinozzi, V. (1958). Sur le 'crane en brosse' au cours de polyglobulies secondaries à l'hypoxémie chronique. Acta Haematologica, 19, 253.

Ginsburg, J. (1963). Hypertrophic pulmonary osteoarthropathy. Postgraduate Medical fournal, 39, 639.

Mariani, M., and Bosman, C. (1962). Uber skelettveranderungen bei kongenitalen herzmissbildungen mit zyanose. Beiträge zur pathologischen Anatomie und zur allgemeinen Pathologie, 126, 145.

Mendlowitz, M., and Leslie, A. (1942). Experimental simulation in the dog of the cyanosis and hypertrophic osteoarthropathy which are associated with congenital heart disease. American Heart fournal, 24, I4I.
Nice, C. M., Daves, M. L., and Wood, G. H. (1964). Changes in bone associated with cyanotic congenital cardiac disease. American Heart fournal, 68, 25.

Trever, R. W. (1958). Hypertrophic osteoarthropathy in association with congenital cyanotic heart disease. A report of two cases. Annals of Internal Medicine, 48, 660 .

Vogl, A., Blumenfeld, S., and Gutner, L. B. (1955). Diagnostic significance of pulmonary hypertrophic osteoarthropathy. American fournal of Medicine, 18, 5 I.

Requests for reprints to Professor P. L. Wahi, Department of Medicine, Postgraduate Institute of Medical Education and Research, Chadigarh, India. 